\title{
Contrasted effect of biochar and earthworms on rice growth and resource allocation in different soils
}

\author{
Diana Noguera $^{\text {a,b,* }}$, Marco Rondón ${ }^{c}$, Kam-Rigne Laossi ${ }^{\mathrm{d}}$, Valerio Hoyos ${ }^{\mathrm{b}}$, Patrick Lavelle ${ }^{\mathrm{a}, \mathrm{b}}$, \\ Maria Helena Cruz de Carvalho ${ }^{\mathrm{e}}$, Sébastien Barot ${ }^{\mathrm{f}}$ \\ a IRD-Bioemco (CNRS, UPMC, ENS, IRD, Paris XII), 32 avenue Henri Varagnat 93143 Bondy Cedex, France \\ ${ }^{\mathrm{b}}$ Centro Internacional de Agricultura Tropical (CIAT), AA 6713, Cali, Colombia \\ ${ }^{\mathrm{C}}$ International Development Research Centre Ottawa, Canada K1G3H9 \\ d Laboratoire d'Ecologie - EA 1293 ECODIV, UFR Sciences et Techniques, Université de Rouen, F-76821 Mont Saint Aignan Cedex, France \\ e Paris XII-Bioemco, (CNRS, UPMC,ENS, IRD, Paris XII), 61 avenue du Général De gaulle - 94010 Créteil Cedex, France \\ ${ }^{\mathrm{f}}$ IRD-Bioemco (CNRS, UPMC, ENS, IRD, Paris XII), Ecole Normale Supérieure, 46 rue d'Ulm 75230 Paris cedex 05, France
}

\section{A R T I C L E I N F O}

\section{Article history:}

Received 11 October 2009

Received in revised form

21 February 2010

Accepted 2 March 2010

Available online 16 March 2010

\section{Keywords:}

Ecological engineering

Oryza sativa

Plant growth

Earthworm

Pontoscolex corethrurus

Resource allocation

Shoot/root ratio

Biochar

Nitrogen

\section{Introduction}

Managing soil fauna (especially earthworms Lavelle et al., 2001) and biochar applications (Lehmann et al., 2003c; Glaser, 2007) are often proposed as appealing ways to increase the fertility of tropical soils in a sustainable way. Indeed, tropical soils are often poor in organic matter (Tiessen et al., 1994) and tend to have low cation exchange capacitites (Glaser, 2007) and both earthworms and biochar influence soil organic matter dynamics, the release of mineral nutriments and their retention. While studying the effect of biochar on plant growth is a fairly new field of researches

\footnotetext{
* Corresponding author at: IRD-Bioemco (CNRS, UPMC, ENS, IRD, Paris XII), 32 avenue Henri Varagnat 93143 Bondy Cedex, France. Tel.: +33148025501.

E-mail address: diana.noguera@bondy.ird.fr (D. Noguera).
}

(Lehmann and Rondon, 2006; Steiner et al., 2008; Blackwell et al., 2009), effects of earthworms on plant growth is an old field. Nevertheless, this issue has mostly been addressed in terms of biomass accumulation and more seldomly in term of resource allocation (Scheu, 2003; Laossi et al., 2009). Our study aims at meeting this need and particularly at determining the effect of biochar and earthworms on plant resource allocation and at infering the underlying mechanisms. Moreover, comparing biochar and earthworm effects that influence soil properties and plant growth partially (and only partially) through the same mechanisms, should throw new lights on this broad subject.

The application of biochar, i.e. incompletely combusted organic matter, (Glaser et al., 2002; Lehmann et al., 2003c) is historically not a new practice. It has re-emerged after the study of the Terra Preta do Indio, which are highly fertile soils (Lehmann et al., 2003c). These soils were created by Amerindian populations in 
pre-Columbian times (Glaser et al., 2002). Apart from high SOM contents, the most striking feature of Terra Preta, is their high nutrient content (Glaser, 2007). This suggests that creating modern Terra Preta could be a way to increase tropical soil fertility and to maintain higher soil carbon stocks, thus mitigating the current rise in atmospheric $\mathrm{CO}_{2}$ (Marris, 2006). Biochar can enhance long-term soil fertility through several mechanisms. The polycyclic aromatic structure of biochar makes it chemically and biologically stable, allowing it to persist in the environment for centuries (DeLuca et al., 2006). Besides this remarkable chemical structure, biochar has a porous physical structure which leads to very large surface area (Lehmann and Rondon, 2006). This increases the soil cation exchange capacity as well as its capacity to retain dissolved organic matter (Lehmann and Rondon, 2006). Moreover, biochar modifies the community of soil microorganisms as well as their activity, probably because it provides a suitable habitat for them (Pietikäinen and Fritze, 2000). This is likely to improve directly and indirectly plant growth (Reynolds et al., 2003; Marris, 2006).

Maintaining high biomasses of earthworms would be another sustainable way to increase tropical soil fertility (Lavelle et al., 2001). Two reviews about the effect of earthworms on plant growth (Brown et al., 1999; Scheu, 2003) showed that plant shoot biomass is higher in the presence of earthworms $(70-80 \%$ of the reviewed experiments). Five mechanisms have been shown to be involved in these positive effects (Brown et al., 2004a): (1) increased mineralization of soil organic matter therefore increasing nutrient availability; (2) production of plant growth substances via the stimulation of microbial activity; (3) biocontrol of pests and parasites; (4) stimulation of symbionts and (5) modification of soil porosity and aggregation which induces changes in water and oxygen availability to plants.

Manipulating earthworms and soil content in biochar are two ways to manipulate soil fertility in the spirit of agroecology and ecological engineering. Indeed, in the two cases, soil physicochemical and biotic characteristics are modified interactively through ecological processes, which could allow a more parsimonious use of industrially produced fertilizers. Biochar and earthworms influence plant growth through mechanisms that are partially the same: they both change soil structure and soil microbial community (Pietikäinen and Fritze, 2000; Brown et al., 2004a) and influence nutrient cycling. While, earthworms increase organic matter mineralization on the short term (Scheu, 2003; Brown et al., 2004a), biochar increases the retention of mineral nutrients (Lehmann and Rondon, 2006) which decreases lixiviation and is likely to increase nutrient availability on the long term (Lehmann and Rondon, 2006; Lehmann et al., 2006). Finally, biochar and earthworms have been shown to directly interact: earthworms ingest biochar particles and reject them in their casts, which is likely to influence biochar distribution in the soil profile (Topoliantz and Ponge, 2003; Topoliantz et al., 2005, Van Zwieten et al., 2009). Therefore, we hypothesize that earthworms and biochar interact in the ways they influence plant growth. To test this hypothesis and to compare the respective effect of earthworms and biochar we investigated, in a greenhouse microcosm experiment, the effects of earthworms (Pontoscolex corethrurus) and biochar on rice growth (Oryza sativa).

It has already been shown that earthworm effects on plant growth change with soil type (Doube et al., 1997; Wurst and Jones, 2003; Brown et al., 2004a; Laossi et al., 2010) but the effect of biochar on plant growth across different soil types has never been directly studied. Therefore, in the present work, each treatment (eathworm and biochar) was implemented in three different soil treatments: two unfertilized soils of contrasted fertility, and the lower-fertility soil supplemented with mineral fertilizer. Assessing the responsiveness of crops to biochar and earthworms in different soils and according to agricultural practices is indeed required to determine where and when using biochar and earthworms improves crop sustainability. This should also help infering the underlying mechanisms (Blouin et al., 2006; Laossi et al., 2010).

Finally, the effect of earthworms and biochar on total plant biomass production has been studied much more than their effects on plant resource allocation. We thus also analyzed the way earthworms and biochar influence the allocation to seeds, roots and shoots, root system architecture and allocation of nitrogen. This is for example useful to determine whether earthworms and biochar increase crop yield (here, the total grain biomass) or only increase the accumulation of vegetative biomasses. This should also give insights on the mechanisms through which earthworms and biochar influence plants. Altogether, the following questions were specifically addressed: (1) What is the relative impact of biochar and earthworms on rice growth? (2) Do soil types and tretaments cause changes in rice responsiveness to earthworm and biochar? (3) Do earthworms and biochar interact in the way they influence rice growth? (4) In which way earthworms and biochar modify resource allocation in rice plants?

\section{Materials and methods}

\subsection{Experimental design}

The experiment was conducted at CIAT (Centro Internacional de Agricultura Tropical) greenhouses in Cali, Colombia. Plants were submitted to the four possible combinations of two factors, each one determined by the presence/absence respectively of earthworms and biochar. All the following treatments combinations were implemented in three soils treatments (see below): biochar $\mathrm{x}$ earthworms (BE), biochar (B), earthworms (E) and control (C) and five replicates were implemented for each treatment combination, resulting in 60 microcosms. Rice was grown in greenhouses for three months under controlled conditions: relative humidity $=65-95 \%$, temperature $=27-29^{\circ} \mathrm{C}$, light intensity $=600 \mu \mathrm{mol}$ $\mathrm{m}^{-2} \mathrm{~s}^{-1}$ and a $12 \mathrm{~h}$ photoperiod.

\subsection{Microcosms}

Containers (microcosms) consisted of PVC pots (diameter $10 \mathrm{~cm}$ and $15 \mathrm{~cm}$ height). They were filled with $900 \mathrm{~g}$ of sieved $(2 \mathrm{~mm})$ dry soil. Drains at the bottom of pots were covered with $1 \mathrm{~mm}$ plastic mesh to prevent earthworms from escaping. Soil was maintained at $80 \%$ soil field capacity (checked through regular weighing of the pots).

Microcosms were arranged in a completely randomized design. The soil was collected in July 2006, during the rainy season, from two long-term field experiments that aimed at comparing plant production in plots with and without the addition of biochar: (1) an experiment on coffee that was established in 2004, in the Andean hillsides of the Cauca Department, south-western Colombia (Pescador, $2^{\circ} 48^{\prime} \mathrm{N} 76^{\circ} 33^{\prime} \mathrm{W}$ ), (2) an experiment on grass and corn production that was established in 2002 (Matazul, $4^{\circ} 19^{\prime} \mathrm{N}, 72^{\circ} 39^{\prime} \mathrm{W}$ in the Colombian Eastern Plains, Llanos). Soil was collected in the control treatments of these experiments for our microcosm treatments without biochar, and from their biochar treatments for our microcosm treatments with biochar. The rate of biochar application was respectively 25.5 and $45.5 \mathrm{~g}$ of biochar per dry kg of soil for "Pescador" and "Matazul" in the 0-10 layer. Since we collected the soil from the same layer, these rates also correspond to the rates of biochar application in our microcosms. In the two cases, biochar was ground mechanically to pass through a $5 \mathrm{~mm}$ mesh. For Pescador, biochar was produced from logs of Eucalyptus deglupta: temperature was maintained at $350{ }^{\circ} \mathrm{C}$ and the oxygen level at $15 \%$, 
the charring time was one hour (Rondon et al. 2007). This led to the following characteristics for Pescador: total C, 82.4\%; total N 0.57\%; $\mathrm{P}, 580 \mu \mathrm{g} \mathrm{g}^{-1}$; CEC, $46.9 \mathrm{mmol} \mathrm{kg}^{-1}$. For Matazul, the biochar we used is commonly sold for cooking (Major, 2009a). It had the following characteristics: total C, 72.9\%; total N, 0.76\%; P,

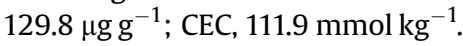

The Pescador soil is a volcanic-ash soil, an inceptisol, in the USDA classification system. This soil is called hereafter the rich soil (R) because of its higher agronomic quality. The soil is moderately acid $\left(\mathrm{pH}\left(\mathrm{H}_{2} \mathrm{O}\right)=5.1\right)$. It is relatively rich in organic matter MO (11.5\%), and mineral nitrogen (12.9 $\mathrm{mg} \mathrm{NH}_{4}^{-}-\mathrm{N} \mathrm{kg}^{-1}, 27 \mathrm{mg} \mathrm{NO}--$ $\left.\mathrm{N} \mathrm{kg}^{-1}\right)$. The CEC is relatively high $\left(6.0 \mathrm{cmol} \mathrm{kg}^{-1}\right)$. Texture is dominated by clay ( $24.06 \%$ sand, $27.56 \%$ silt, and $48.38 \%$ clay). The soil bulk density is $0.8 \mathrm{~g} \mathrm{~cm}^{-3}$.

The Matazul soil is a clay-loam oxisol which has developed from alluvial sediments (Rippstein et al., 2001). It is hereafter refered to this soil as the poor soil $(\mathrm{P})$ because it is less fertile that the inceptisol. This soil is slightly more acid $\left(\mathrm{pH}\left(\mathrm{H}_{2} \mathrm{O}\right)=4.3\right)$ than the $\mathrm{R}$ soil. The contents in organic matter (5.22\%) and mineral nitrogen (4.32 mg NH $\mathrm{NH} \mathrm{kg}^{-1}, 7.39 \mathrm{mg}, \mathrm{NO}_{3}^{-}-\mathrm{N} \mathrm{kg}^{-1}$ ) are much lower than in the $\mathrm{R}$ soil. The soil has a low capacity to retain cations (CEC $3.0 \mathrm{cmol} \mathrm{kg}^{-1}$ ). The soil has a rather equilibrated texture (41.23\% sand, $23.78 \%$ silt and $34.39 \%$ clay). (Gijsman et al., 1997). The bulk density in the native savanna is $1.30 \mathrm{~g} \mathrm{~cm}^{-3}$ (Trujillo et al., 1998). A last soil treatment $(P+F)$ was implemented in our experiment. It consists in the soil of the grassland oxisol to which fertilizer was added in our microcosms. The $\mathrm{P}+\mathrm{F}$ treatment received three times a NPK treatment $(20,20$ and $40 \mathrm{~kg}$ ha- 1 , respectively for $\mathrm{P}, \mathrm{K}$ and $\mathrm{N}$ ) on day 20,30 and 45 . $\mathrm{N}$ was provided as urea, $\mathrm{P}$ as acidified rock phosphate and $\mathrm{K}$ as $\mathrm{KCl}$.

We use the terms "poor soil" and "rich soil" to facilitate the comprehension of our article. However, the two soils are very different and differ by many other characteristics than their content in organic matter and mineral nutrients. These characteristics are also likely to influence the effects of biochar and earthworms on plant growth (see the Discussion).

For each microcosm, five adults (initial total fresh weight 4.0 ( $\pm 0.5 \mathrm{~g}$ ) of $P$. corethrurus (Annelida: Oligocheata: Glossoscolecidae), were introduced. Earthworms were collected at the Pescador site (Cauca, Colombia). This species is not present in Matazul but is very widespread in the humid tropics and is able to colonize many different types of habitat, which is the main reason for the choice of this species. Individuals for Matazul soil microcosms were aclimated in this soil during one week. Two days after introducing earthworms, 5 rice seeds (O. sativa cv. Linea 30, Chatel et al., 2003) were sown. After 2 weeks, only one seedling was kept in each microcosm and these were regularly weeded during the experiment (other seedlings were removed).

\subsection{Measurements}

After ten weeks, plants were harvested and separated into grains, leaves, and stems. Roots were collected by wet sieving. Fresh root systems were scanned and analysed using a digital image analysing system (WinRHIZO, version 2003b, Regent Instrument, Quebec, Canada). Each plant part was dried in an electric oven at $60{ }^{\circ} \mathrm{C}$ for 2 days and weighted. This material was then cut in small pieces (leaves and roots) and random subsamples were randomly selected to measure total carbon, total nitrogen and $\mathrm{C} / \mathrm{N}$ with a Thermo Finnigan Elementary Analyser Flash EA1112. The plant variables considered were: total biomass, shoot biomass, root biomass, total grain biomass, total root length, mean root diameter, shoot root ratio, root ramification, mean grain weight, grain number, grain $\mathrm{C} / \mathrm{N}$, root $\mathrm{C} / \mathrm{N}$, leaf $\mathrm{C} / \mathrm{N}$ and total $\mathrm{N}$ content in rice. Besides, at harvest time, a soil sample was collected for chemical analyses. Nitrate and ammonium were quantified colorimetrically using a segmented flow analyzer (Skalar Autoanalyzer, Skalar, The Netherlands).

\subsection{Statistical analysis}

ANOVAs were implemented using the SAS GLM procedure (sum of squares type III, SS3) (SAS, 1990). Residual normality and homocedasticity were verified using Kolmogrov-Smirnov and Bartlett tests. A full model was first used to test all possible factors: Biochar (B), earthworms (E) and soil (S) and all, two-fold and three-fold, interactions between these factors. Since significant interactions between biochar and soil and earthworms and soil were detected, data were reanalysed separately for each soil (Tables 1-4). This allowed displaying complicated results in a more pedagogic way. To determine the direction of significant effects, we used multiple comparison tests based of least square means (hereafter LS means, LS means SAS statement), taking into account the Bonferroni correction.

\section{Results}

For all ANOVAs the $R^{2}$ values are very high, i.e. above 0.70 in most cases, and above 0.90 in many cases (see Tables $1-4$ ). This shows that a high percentage of the measurment variability is explained by the treatments. The percentages of variation given below are relative to the control treatment and all correspond to significant LS means comparisons.

\subsection{Soil content in nitrate and ammonium}

Biochar and earthworms tend to increase both the nitrate and the ammonium contents of the soil in the three soil treatments (Table 1, Fig. 1). However, in the R soil, earthworms increase soil mineral nitrogen content $(+92 \%$ for nitrate and $+80 \%$ for ammonium) more than biochar ( $+44 \%$ for nitrate and $+12 \%$ for ammonium). Conversely, biochar does not affect soil nitrate content in the $\mathrm{P}+\mathrm{F}$ soil treatment. Biochar and earthworm effects are most of the time additive, but there are also some exceptions. For example, in the P soil, both biochar and earthworms increase soil content in nitrate and ammonium, but the combination of the two does not increase further this content. Conversely, in the fertilization treatment, soil ammonium content decreases with earthworms $(-7 \%)$, increases with biochar $(+14 \%)$, and increases more in the presence of both biochar and earthworms $(+40 \%)$.

\subsection{Total biomasses and allocation to reproduction and roots}

The shoot and total biomasses are higher in the $\mathrm{R}$ and $\mathrm{P}+\mathrm{F}$ soils than in the $\mathrm{P}$ soil (Fig. 2). Root and total grain biomasses are comparable in the two P soil treatments and higher in the $\mathrm{R}$ soil. There is a significant effect of $\mathrm{E}$ and $\mathrm{B}$ in most cases. The interaction between $\mathrm{E}$ and $\mathrm{B}$ is only significant for the root, grain and total biomasses in the $\mathrm{P}$ soil and for the root biomass in the $\mathrm{P}+\mathrm{F}$ soil. There is no significant effect on the shoot/root ratio in the P soil and on the total and shoot biomasses in the $\mathrm{P}+\mathrm{F}$ soil (Table 2 ).

The total and shoot biomasses follow the same pattern. In the $\mathrm{R}$ soil, the effects of $E$ and $B$ are both significant but the effect of $B$ $(+147$ and $+166 \%)$ is stronger than the effect of $E(+82$ and $+98 \%$ respectively). The two effects are additive (no interaction). In the $\mathrm{P}+\mathrm{F}$ soil, there is no significant effect on the total and shoot biomasses. In the P soil, the clearer effect on the total and shot biomasses is a positive $\mathrm{E}$ effect ( +167 and $+200 \%$ respectively). It must be highlighted that the combination of $\mathrm{E}$ and $\mathrm{B}$ allows 
Table 1

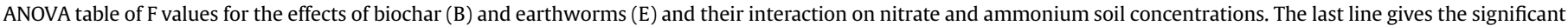

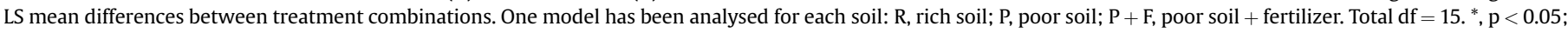
${ }^{* *}, \mathrm{p}<0.01$; ***, $\mathrm{p}<0.001$; NS not significant.

\begin{tabular}{|c|c|c|c|c|c|c|c|}
\hline & \multirow[t]{2}{*}{$d f$} & \multicolumn{2}{|l|}{$\mathrm{R}$} & \multicolumn{2}{|l|}{$\mathrm{P}$} & \multicolumn{2}{|l|}{$\mathrm{P}+\mathrm{F}$} \\
\hline & & Nitrate & Ammonium & Nitrate & Ammonium & Nitrate & Ammonium \\
\hline $\mathrm{B}$ & 3 & 19.20* & $10.88^{*}$ & $25.75^{* *}$ & 414.18 ${ }^{* * *}$ & $2.27 \mathrm{NS}$ & $60.71^{* * *}$ \\
\hline E & 3 & 75.46 ${ }^{* * *}$ & $45.62^{* * *}$ & 22.10** & 261.13*** & 21.24* & $5.91^{*}$ \\
\hline $\mathrm{E} \times \mathrm{B}$ & 3 & 0.18 NS & $4.61^{* * *}$ & $12.53^{* *}$ & $499.24^{* * *}$ & $1.63 \mathrm{NS}$ & $17.32^{*}$ \\
\hline$R^{2}$ & & 0.922 & 0.884 & 0.883 & 0.993 & 0.758 & 0.912 \\
\hline LS means & & $E B>E>B>C$ & $E B>E>B>C$ & $\mathrm{~EB}, \mathrm{~B}, \mathrm{E}>\mathrm{C}$ & $E B, B, E>C$ & $E B, E>B, C$ & $\mathrm{~EB}>\mathrm{B}, \mathrm{E}, \mathrm{C}$ \\
\hline
\end{tabular}

reaching the same total biomasses as the ones obtained in the $\mathrm{P}+\mathrm{F}$ soil.

The root biomass follows a different pattern than the shoot and total biomasses. In the three soils, the stronger effect is a positive $\mathrm{E}$ effect (Fig. 2). In the $\mathrm{P}+\mathrm{F}$ soil the pattern is more complicated due to a significant interaction between $\mathrm{B}$ and $\mathrm{E}$.

The total grain biomass follows another original pattern. In the R soil there are positive $\mathrm{E}(+92 \%)$ and $\mathrm{B}(+294 \%)$ effects. In the P soil there is an interaction between $\mathrm{E}$ and $\mathrm{B}$ leading to $\mathrm{a}+800 \%$ increase in total grain biomass in the $\mathrm{E}$ and $\mathrm{B}$ treatment. In the $\mathrm{P}+\mathrm{F}$ soil there is only a negative $E$ effect on the total grain biomass ( $-21 \%)$.

\subsection{Allocation of resources within the aerial and root systems}

All variables but root ramification are influenced by the soil treatment (Fig. 3). In general, variables take higher values in the $\mathrm{P}+\mathrm{F}$ soil. Differences between the $\mathrm{R}$ and $\mathrm{P}$ soils tend to be less clear. However, the mean grain weight and the grain number are higher in the $\mathrm{R}$ than in the $\mathrm{P}$ soil. Besides, the mean grain weight is comparable in the $\mathrm{P}$ and $\mathrm{P}+\mathrm{F}$ soils but higher in the $\mathrm{R}$ soil.

The total root length and the mean root diameter follow roughly the same pattern (Fig. 3 and Table 3, LS means comparisons). In all soil treatments, the E and B treatments tend to lead to root systems with higher total root length and root diameter. The effect of B and

\section{Table 2}

ANOVA table of $F$ values for the effects of biochar (B) and earthworms (E) and their interaction on Total biomass, Shoot biomass, Root biomass and Total grain biomass. The last line gives the significant LS mean differences between treatment combinations. One model has been analysed for each soil: $\mathrm{R}$, rich soil; $\mathrm{P}$, poor soil; $\mathrm{P}+\mathrm{F}$, poor soil + fertilizer. Total $\mathrm{df}=19$. $^{*}$; ${ }^{* *}$; ${ }^{* * *} \mathrm{p}<0.05, \mathrm{p}<0.01, \mathrm{p}<0.001$, NS not significant.

\begin{tabular}{|c|c|c|c|c|c|}
\hline & $d f$ & $\begin{array}{l}\text { Total } \\
\text { biomass }\end{array}$ & $\begin{array}{l}\text { Shoot } \\
\text { biomass }\end{array}$ & $\begin{array}{l}\text { Root } \\
\text { biomass }\end{array}$ & $\begin{array}{l}\text { Total grain } \\
\text { biomass }\end{array}$ \\
\hline \multicolumn{6}{|c|}{$\mathbf{R}$} \\
\hline B & 1 & $213.04^{* * *}$ & $191.44^{* * *}$ & 0.19 N.S. & $174.37^{* * *}$ \\
\hline E & 1 & 75.28 *** & 78.31 *** & $13.75^{* * *}$ & 25.96 *** \\
\hline $\mathrm{E} \times \mathrm{B}$ & 1 & 1.69 N.S. & 1.82 N.S. & 0.29 N.S. & 2.00 N.S. \\
\hline$R^{2}$ & & 0.95 & 0.94 & 0.470 & 0.92 \\
\hline means & & $E B>B>E>C$ & $E B>B>E>C$ & $\mathrm{~EB}, \mathrm{E}>\mathrm{B}, \mathrm{C}$ & $\mathrm{EB}>\mathrm{B}>\mathrm{E}>\mathrm{C}$ \\
\hline \multicolumn{6}{|l|}{$\mathbf{P}$} \\
\hline B & 1 & $20.74 * * *$ & 4.42 N.S. & $10.79^{* * *}$ & 38.06 *** \\
\hline E & 1 & 138.32 *** & $96.11^{* * *}$ & $87.20 * * *$ & $12.82^{* *}$ \\
\hline $\mathrm{E} \times \mathrm{B}$ & 1 & $6.23^{*}$ & 0.61 N.S. & $5.37^{*}$ & $13.93^{* *}$ \\
\hline$R^{2}$ & & 0.91 & 0.86 & 0.86 & 0.80 \\
\hline LS means & & $E B, E>B, C$ & $\mathrm{~EB}, \mathrm{E}>\mathrm{B}, \mathrm{C}$ & EB, $\mathrm{E}>\mathrm{B}, \mathrm{C}$ & $\mathrm{EB}>\mathrm{B}, \mathrm{E}, \mathrm{C}$ \\
\hline \multicolumn{6}{|l|}{$\mathbf{P}+\mathbf{F}$} \\
\hline B & 1 & 0 NS & 1.71 N.S. & 36.98 *** & 0.14 N.S. \\
\hline E & 1 & 2.31 N.S. & 0.42 N.S. & 96.10*** & $11.92^{*}$ \\
\hline $\mathrm{E} \times>\mathrm{B}$ & 1 & $1.49 \mathrm{NS}$ & 0 N.S. & $15.23^{* *}$ & 1.28 N.S. \\
\hline$R^{2}$ & & 0.19 & 0.12 & 0.90 & 0.45 \\
\hline LS means & & NS & NS & $\begin{array}{l}E>E B>B \\
E>C\end{array}$ & B, C > E, EB \\
\hline
\end{tabular}

the interaction between $\mathrm{E}$ and $\mathrm{B}$ determine the ranking between the four treatment combinations. Although B effect and this interaction are significant in the $R$ and $P$ soils but not in the $P+F$ soils, $L S$ means comparisons show that in the three soil treatments the combination of earthworms and biochar tend to lead to higher total root lengths and root diameters than other treatment combinations. The number of ramifications per unit of root length (root ramification) presents a higher variability within treatments than other root related variables (Fig. 3). However, for the R, P and P + F soils, $\mathrm{E}$ has a positive effect $(+22 \%,+34 \%$ and $32 \%$ respectively) on root ramification, while $\mathrm{B}$ has a negative effect only in the $\mathrm{R}$ soil (-24\%, Fig. 3).

The shoot/root ratio follows a different pattern from the root biomass. In particular, the $\mathrm{E}$ and $\mathrm{B}$ effects are different in the three soils. In the R soil there is only a positive effect of $B(+220 \%)$ on the shoot/root ratio, i.e. decrease in the proportion of resources allocated to roots. In the $\mathrm{P}$ soil there is no significant effect of the treatments. In the $\mathrm{P}+\mathrm{F}$ soil there is a positive $\mathrm{B}$ effect $(+20 \%)$ and a negative $\mathrm{E}$ effect $(-45 \%)$ on the shoot/root ratio (which leads to a complex ranking of treatments as described by LS mean comparisons, Table 3).

Grain production and grain filling were very limited in the P soil. This leads to small and very variable values for the mean grain weight and the grain number (Fig. 3). There is no significant effect on the mean grain weight in the R soil (Table 3$)$. However, in this soil, there are significant positive $\mathrm{E}(+55 \%)$ and $\mathrm{B}(+232 \%)$ effects on the grain number. In the $P$ soil, there is no significant effect on the mean grain biomass, but positive $\mathrm{E}(+150 \%)$ and B effects $(+250 \%)$ on the grain number. Finally, in the $\mathrm{P}+\mathrm{F}$ soil there is a negative $\mathrm{E}$ effect on the mean grain weight and no significant effect on the grain number.

\section{4. $C / N$ ratios and total nitrogen content}

$\mathrm{C} / \mathrm{N}$ ratios do not markedly differ between soil types. However, the total nitrogen content is higher in $\mathrm{R}$ and $\mathrm{P}+\mathrm{F}$ soils than in the $\mathrm{P}$ soil (Fig. 4). Earthworms tend to decrease the grain, root and leaf $\mathrm{C} / \mathrm{N}$ ratios in the three soils (Fig. 4, Table 4). This effect is significant for the root $(-9 \%)$ and leaf $\mathrm{C} / \mathrm{N}(-40 \%)$ in the R soil; for the leaf $\mathrm{C} / \mathrm{N}$, in the P soil (-32\%); for the grain, root and leaf $C / N(-18 \%,-15 \%$ and $-47 \%$ respectively) in the $\mathrm{P}+\mathrm{F}$ soil. Additionally, in the $\mathrm{R}$ soil, biochar increases the grain, root and leaf $\mathrm{C} / \mathrm{N},(+22 \%,+109 \%$ and $+45 \%$ respectively). The only significant interaction between earthworms and biochar is for the grain $\mathrm{C} / \mathrm{N}$ in the $\mathrm{P}+\mathrm{F}$ soil.

Treatment effects on the total nitrogen content highly depend on the soil treatment (Table 4). In the R soil, biochar (three-fold increase) and earthworms $(+30 \%)$ increase the total nitrogen content. There is no significant effect in the P soil. Earthworms decrease the total nitrogen content in the $\mathrm{P}+\mathrm{F}$ soil treatment $(-20 \%)$. There is no significant interaction between earthworm and biochar for the total nitrogen content. 
Table 3

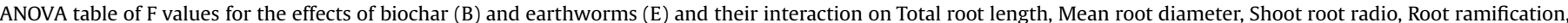

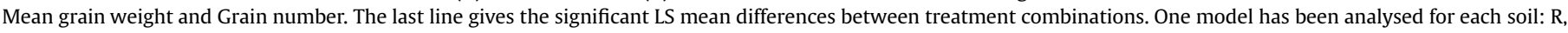
rich soil; $\mathrm{P}$, poor soil; $\mathrm{P}+\mathrm{F}$, poor soil + fertilizer. Total $\mathrm{df}=19$. ${ }^{*} ;{ }^{* *} ;{ }^{* * *} \mathrm{p}<0.05, \mathrm{p}<0.01, \mathrm{p}<0.001$, NS not significant.

\begin{tabular}{|c|c|c|c|c|c|c|c|}
\hline & $d f$ & $\begin{array}{l}\text { Total } \\
\text { root length }\end{array}$ & $\begin{array}{l}\text { Mean root } \\
\text { diameter }\end{array}$ & $\begin{array}{l}\text { Shoot-root } \\
\text { radio }\end{array}$ & $\begin{array}{l}\text { Root } \\
\text { ramification }\end{array}$ & $\begin{array}{l}\text { Mean grain } \\
\text { Weight }\end{array}$ & $\begin{array}{l}\text { Grain } \\
\text { number }\end{array}$ \\
\hline \multicolumn{8}{|l|}{$\mathbf{R}$} \\
\hline B & 1 & $13.47^{* *}$ & $10.06^{* *}$ & $122.58^{* * *}$ & $8.42^{* *}$ & 1.29 N.S. & $178.34^{* * *}$ \\
\hline E & 1 & $33.91 * * *$ & $6.97^{*}$ & 0.69 N.S. & $15.23^{* *}$ & 2.76 N.S. & $17.71^{* * *}$ \\
\hline $\mathrm{E} \times \mathrm{B}$ & 1 & $11.81^{* *}$ & 0.41 N.S. & 0.25 N.S. & 0.51 N.S. & 0.63 N.S. & 1.75 N.S. \\
\hline$R^{2}$ & & 0.78 & 0.52 & 0.88 & 0.60 & 0.22 & 0.92 \\
\hline LS means & & $\mathrm{EB}>\mathrm{B}, \mathrm{E}, \mathrm{C}$ & $\mathbf{E B}>\mathbf{C}$ & EB, $B>E, C$ & $E B, E>B$ & NS & $\mathbf{E B}>\mathbf{B}>\mathbf{E}>\mathbf{C}$ \\
\hline \multicolumn{8}{|l|}{$\mathbf{P}$} \\
\hline B & 1 & $29.89 * * *$ & $10.17^{* *}$ & 0.66 N.S. & 1.32 N.S. & 2.97 N.S. & $18.56^{* * *}$ \\
\hline $\mathrm{E}$ & 1 & $54.71^{* * *}$ & $35.10 * * *$ & 0.10 N.S. & $12.32 * *$ & 1.09 N.S. & $12.89 * *$ \\
\hline $\mathrm{E} \times \mathrm{B}$ & 1 & $18.22^{* * *}$ & $8.15^{*}$ & 0.99 N.S. & 0.19 N.S. & 0.76 N.S. & 6.31 N.S. \\
\hline$R^{2}$ & & 0.86 & 0.76 & 0.41 & 0.46 & 0.22 & 0.70 \\
\hline LS means & & $\mathrm{EB}>\mathrm{B}, \mathrm{E}, \mathrm{C}$ & $\mathrm{EB}>\mathrm{B}, \mathrm{E}, \mathrm{C}$ & NS & EB, E $>$ B,C & NS & $\mathrm{EB}>\mathrm{B}, \mathrm{E}, \mathrm{C}$ \\
\hline \multicolumn{8}{|l|}{$\mathbf{P}+\mathbf{F}$} \\
\hline B & 1 & 2.08 N.S. & 1.78 N.S. & $10.99 * *$ & 0.91 N.S. & 1.44 N.S. & 0.29 N.S. \\
\hline $\mathrm{E}$ & 1 & $11.3^{* *}$ & 2.33 N.S. & $50.96 * * *$ & $36.82^{* * *}$ & $13.61^{* *}$ & 0.79 N.S. \\
\hline $\mathrm{E} \times \mathrm{B}$ & 1 & 0.98 N.S. & 0.78 N.S. & 0.4 N.S. & 1.25 N.S. & 3.73 N.S. & 0.15 N.S. \\
\hline$R^{2}$ & & 0.47 & 0.23 & 0.79 & 0.70 & 0.53 & 0.07 \\
\hline LS means & & $E B, E>B, C$ & NS & $\begin{array}{l}B>E B, E \\
C>E\end{array}$ & $E B, E>B, C$ & $\mathrm{~B}, \mathrm{C}>\mathrm{EB}, \mathrm{E}$ & NS \\
\hline
\end{tabular}

\section{Discussion}

In our study, there are more significant effects of earthworms than significant effects of biochar on rice growth and related traits (first question in the introduction). However this is due to the fact that earthworms and biochar effects depend on the soil type (second question). While there are many significant effects of earthworms and biochar in the R soil, there are mostly significant earthworm effects in the P soil. In the same vein, the fertilization of the $P$ soil tends to decrease the amplitude of earthworms and biochar effects. However, in this fertilization treatment, there are significant earthworm effects on some plant traits and significant biochar effects on other traits. Contrary to our expectation few significant effects of the interactions between earthworms and

Table 4

ANOVA table of $F$ values for the effects of biochar (B) and earthworms (E) and their interaction on Grain $\mathrm{C} / \mathrm{N}$, Root $\mathrm{C} / \mathrm{N}$, Leaf $\mathrm{C} / \mathrm{N}$ and Total $\mathrm{N}$ content. The last line gives the significant LS mean differences between treatment combinations. One model has been analysed for each soil: $R$, rich soil; P, poor soil; $P+F$, poor soil + fertilizer. Total $\mathrm{df}=15$ for all models but for the Grain $\mathrm{C} / \mathrm{N}$ in the $\mathrm{P}$ soil where the low grain biomasses did not allow for enough $\mathrm{C} / \mathrm{N}$ measurements, and the model was not run. ${ }^{*} ;{ }^{* *} ;{ }^{* * *} \mathrm{p}<0.05, \mathrm{p}<0.01, \mathrm{p}<0.001$, NS not significant.

\begin{tabular}{|c|c|c|c|c|c|}
\hline & $d f$ & Grain $\mathrm{C} / \mathrm{N}$ & $\operatorname{Root} \mathrm{C} / \mathrm{N}$ & Leaf $\mathrm{C} / \mathrm{N}$ & Total $\mathrm{N}$ content \\
\hline \multicolumn{6}{|l|}{$\overline{\mathbf{R}}$} \\
\hline B & 1 & $7.52^{*}$ & 155.53 $^{* * *}$ & $10.61^{* *}$ & $34.08^{* * *}$ \\
\hline E & 1 & 20.13 NS & $13.22^{* *}$ & $19.28^{* * *}$ & 83.70 $^{* * *}$ \\
\hline $\mathrm{E} \times \mathrm{B}$ & 1 & 1.53 N.S. & 5.34 N.S. & 0.61 N.S. & 2.93 N.S. \\
\hline$R^{2}$ & & 0.70 & 0.93 & 0.72 & 0.90 \\
\hline LS means & & EB, $B>E, C$ & $B>E B>E, C$ & $\mathrm{~B}>\mathrm{EB}, \mathrm{E}$ & $E B>E>B>C$ \\
\hline \multicolumn{6}{|l|}{$\mathbf{P}$} \\
\hline B & 1 & - & 2.27 N.S. & 3.04 N.S. & 0.36 NS. \\
\hline E & 1 & - & 1.19 N.S. & $10.92^{* *}$ & $10.60 \mathrm{NS}$ \\
\hline $\mathrm{E} \times \mathrm{B}$ & 1 & - & 3.80 N.S. & 0.39 N.S. & 0.23 NS \\
\hline$R^{2}$ & & - & 0.37 & 0.54 & 0.56 \\
\hline LS means & & - & NS & $B, C>E B, E$ & NS \\
\hline \multicolumn{6}{|l|}{$\mathbf{P}+\mathbf{F}$} \\
\hline B & 1 & 0.10 N.S. & 0.01 N.S. & 0.18 N.S. & 0.31 N.S. \\
\hline E & 1 & 46.42*** & 7.94* & $34.34^{* * *}$ & $60.61^{* *}$ \\
\hline $\mathrm{E} \times \mathrm{B}$ & 1 & 4.53* & 0.05 N.S. & 0.06 N.S. & 1.33 N.S. \\
\hline$R^{2}$ & & 0.80 & 0.39 & 0.74 & 0.83 \\
\hline LS means & & $B, C>E B, E$ & $B, C>E B, E$ & $B, C>E B, E$ & $B, C>E B, E$ \\
\hline
\end{tabular}

biochar were found (third question). The different plant traits present different patterns of responsiveness to earthworms and biochar. For example; traits describing the root system, the $\mathrm{C} / \mathrm{N}$ of the different plant parts and the total biomasses responded differently to earthworms and biochar. Moreover, we have shown that the shoot/root ratio was directly impacted by earthworms and biochar. These results show that earthworms and biochar affect the resource allocation of rice plants (forth question). Linking results on different plant traits, we interpret below our detailed results and infer from them informations on the underlying mechanisms.

\subsection{Effects on soil mineral nitrogen}

The fertilization treatment involved the addition of urea. This led to a clear increase (about five fold) in both nitrate and ammoium soil concentration. This shows that urea quickly mineralized. Earthworms increased the availability of nitrate and ammonium in the three soil treatments as usually found in earthworm experiments (Lavelle and Spain, 2001; Bhattacharya and Chattopadhyay, 2004; Amador and Görres, 2005). This should be due to several mechanisms: microbial activity is stimulated in earthworm fresh casts (Lavelle et al., 1999; Brown et al., 2000; Chaoui et al., 2003), earthworms mix and fragment the organic matter particles they ingest without assimilitaing it (Lavelle et al., 1999), and earthworms assimilate and excrete a part of the nitrogen of the organic matter they ingest (Whalen et al., 2000).

Although the influence of biochar on nitrogen transformation processes in soil is complicated (Singh et al., 2010), biochar globally increased mineral nitrogen concentration in our experiment. This could be due to the fact that biochar increases the CEC and thus increases the retention of cations such as ammonium (Lehmann et al., 2003a,b). The positive effect of biochar on nitrate concentration could be achieved through a retention of water by biochar particles (Glaser et al., 2002). However, biochar did not increase the concentration of nitrate in the fertilization treatment. This could be due to a saturation of the soil by the nitrate coming from the quick mineralization of urea and the subsequent nitrification. Finally, earthworms and biochar alone increased mineral nitrogen concentration in the poor soil but the combination of the two did not increase futher this concentration contrary to what was 

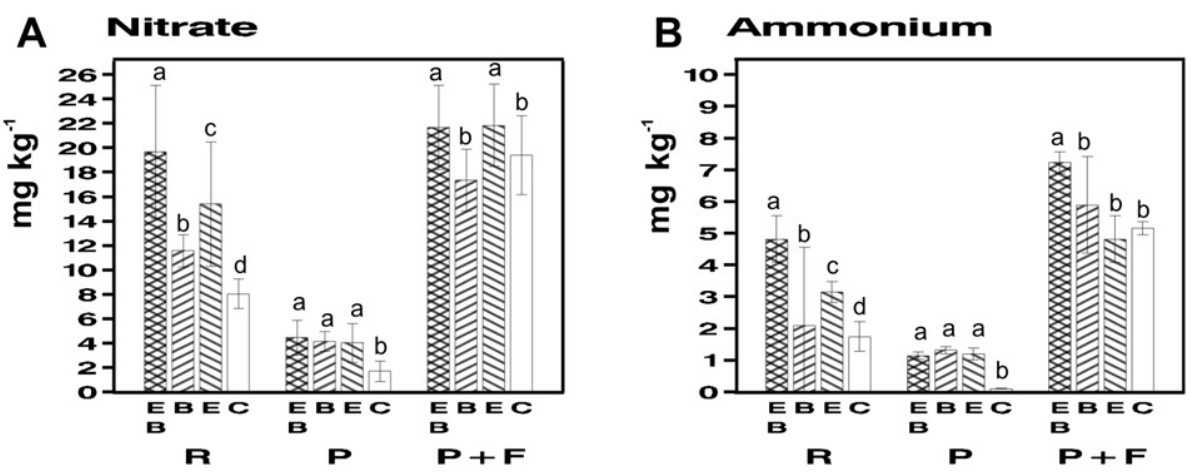

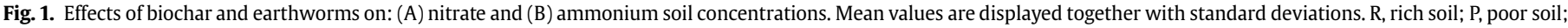

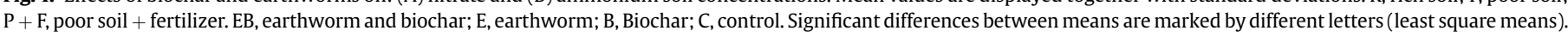

observed in the rich soil. It is not possible to conclude on the underlying mechanism but interactions between earthworms and biochar are possible, for example due to their respective effects on microbial biomass and the consecutive nutrient immobilization by microorganisms.

\subsection{Contrasted effects of biochar and earthworms in the three soil treatments}

Brown et al. (2004a) has remarked that the response of plants to earthworms should depend on the type of soil and it is generally assumed that positive effects of earthworms on plant growth are more likely in poor soils than in rich soils (Doube et al., 1997; Brown et al., 2004b). The rationale behind this hypothesis is that earthworms mostly affect plants because they increase the mineralization of soil organic matter. Hence, if a soil is naturally rich in mineral nutrients or if it is fertilized, earthworm effect should be diluted and could disappear (Blouin et al., 2006). In our case, earthworms increased the total biomass in the poor and rich soils but did not have this effect when the poor soil was fertilized. This effect of fertilization supports the above-mentioned hypothesis and suggests that $P$. corethrurus first increased rice total biomass through an increased mineralization. Although earthworms also increased the soil content in ammonium and nitrate in the fertilization treatment, the impact of this increase was somehow diluted by fertilization.

Rice response to biochar depended on soil type. The positive effect of biochar on the total biomass observed in the rich soil was not seen in the poor soil with or without fertilizer. Using the same rationale than for earthworms (see above), this suggests that biochar mostly affected rice growth because of its positive effect on nutrient retention and availability. That biochar clearly increased
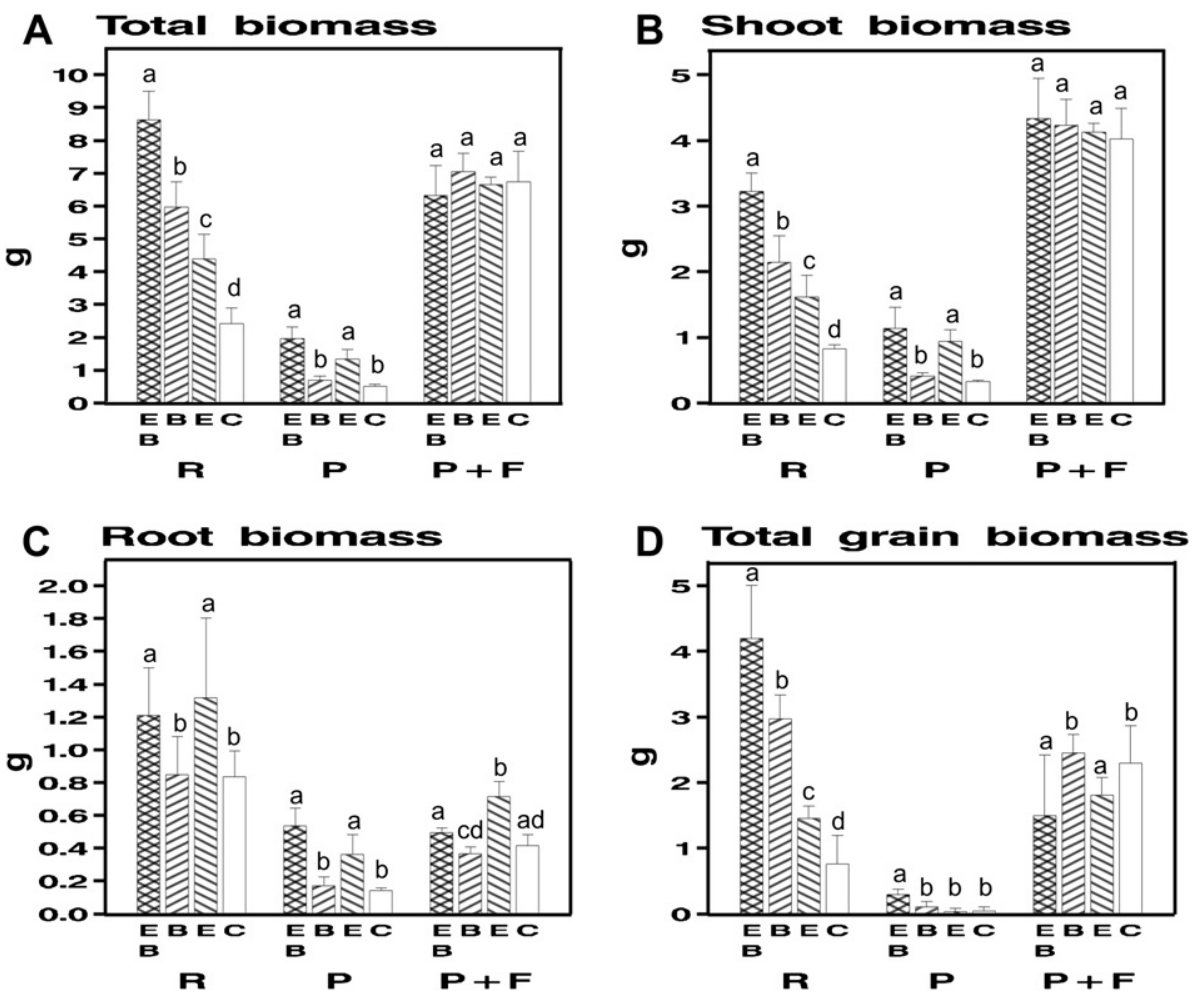

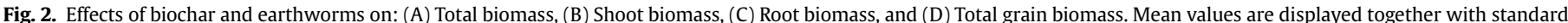

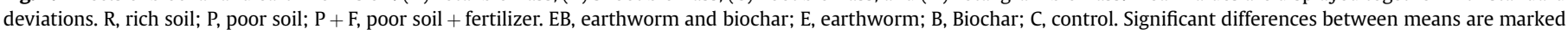
by different letters (least square means). 
A Total root length

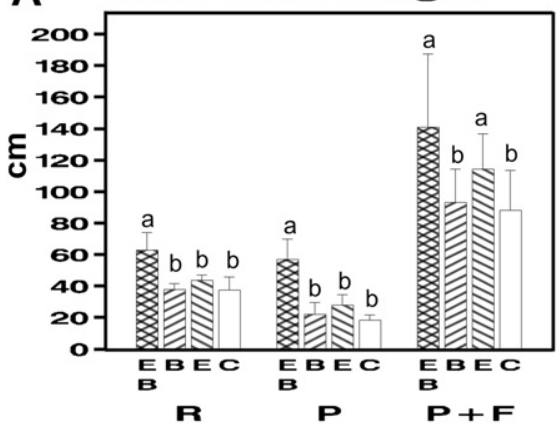

C Shoot root ratio

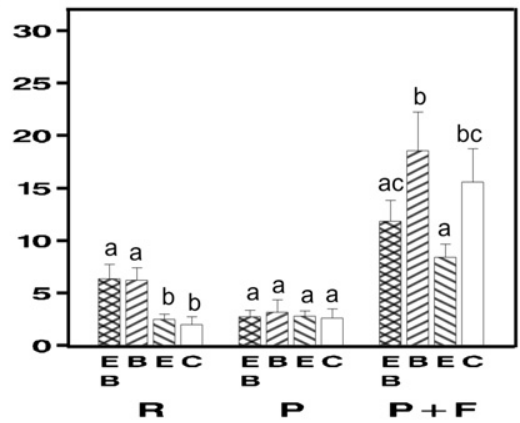

E Mean grain weight

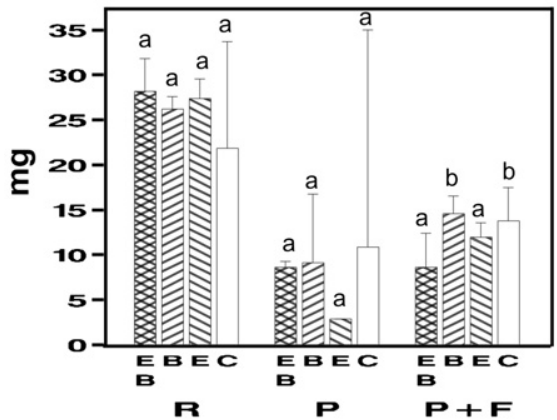

B Mean root diameter

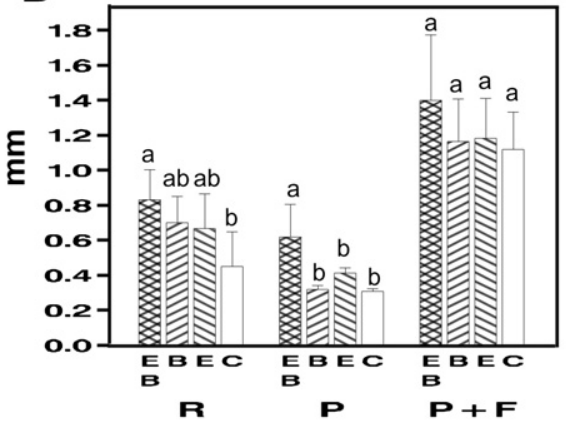

D Root ramification
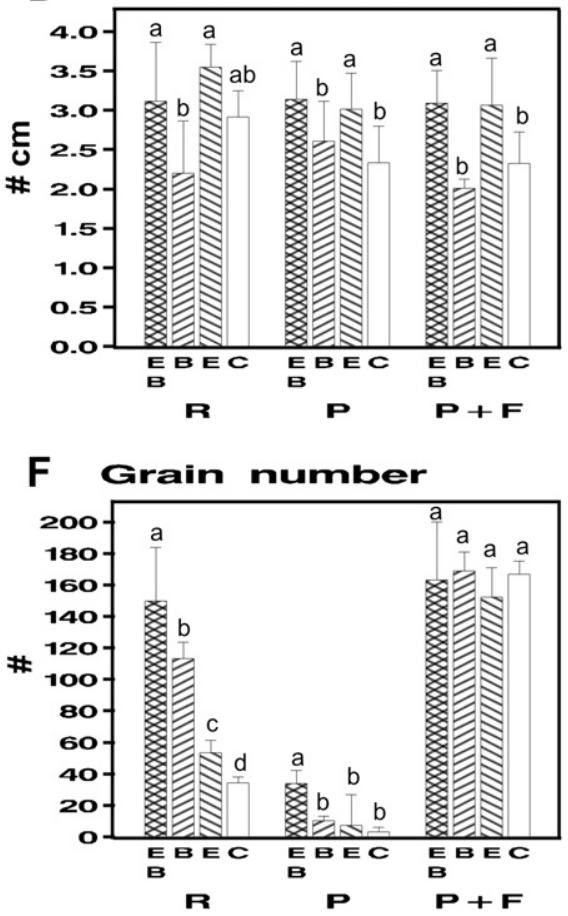

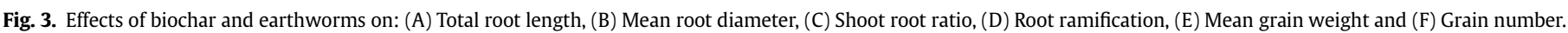

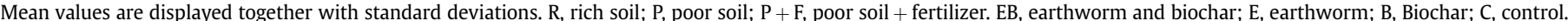
Significant differences between means are marked by different letters (least square means).

the availability of mineral nitrogen in the two soils but not in the fertilization treatment supports further this rational. The absence of biochar effect in the P soil is more difficult to explain. Indeed, field experiments showed that the same biochar treatment in the same soil has a positive effect on maize grown in the field $(+140 \%$, Major et al., 2009 unpublished results of the field experiment from which our soil, with or without biochar, has been extracted). Moreover, (1) the concentration of biochar was higher in the P than in the R soil, (2) the CEC of the biochar used in the P soil was higher than in the R soil, and (3) biochar increased soil content in nitrate and ammonium in the $\mathrm{P}$ soil (see above). A possible explanation would be that $P$ soil being intrinsically poorer in mineral nutrients than the $\mathrm{R}$ soil, biochar effects is lower in the P soils because there are less nutrient to immobilize.

\subsection{Lack of interaction between biochar and earthworms}

There are few significant interacting effects between biochar and earthworms on plant traits and, when there is a significant interaction, it generally has a small effect relatively to earthworm and biochar simple effects. This suggests that the mechanisms through which earthworms and biochar increased rice growth did not interact strongly. This is especially meaningful, in the $\mathrm{R}$ soil where there was a positive biochar and earthworm effect for most plant traits measured. In this soil, earthworm effect is supposed to be due to an increase in mineralization and biochar effect is supposed to be due to a decrease in leaching (see above). These two mechanisms could act in synergy, the first providing more mineral nutrient to the soil, the second helping to maintain them in the soil. That such a synergy was not observed in our experiment could be explained by the short duration of the experiment. Indeed, in the field, earthworms could build up the stock of nutrients immobilized in biochar year after year, which cannot occur in our short-term experiment. Moreover, on the long term, earthworms could also influence nutrient retention which could interact further with biochar, either positively or negatively (Subler et al., 1997; Domínguez et al., 2004; Sheehan et al., 2006; Barot et al., 2007). 

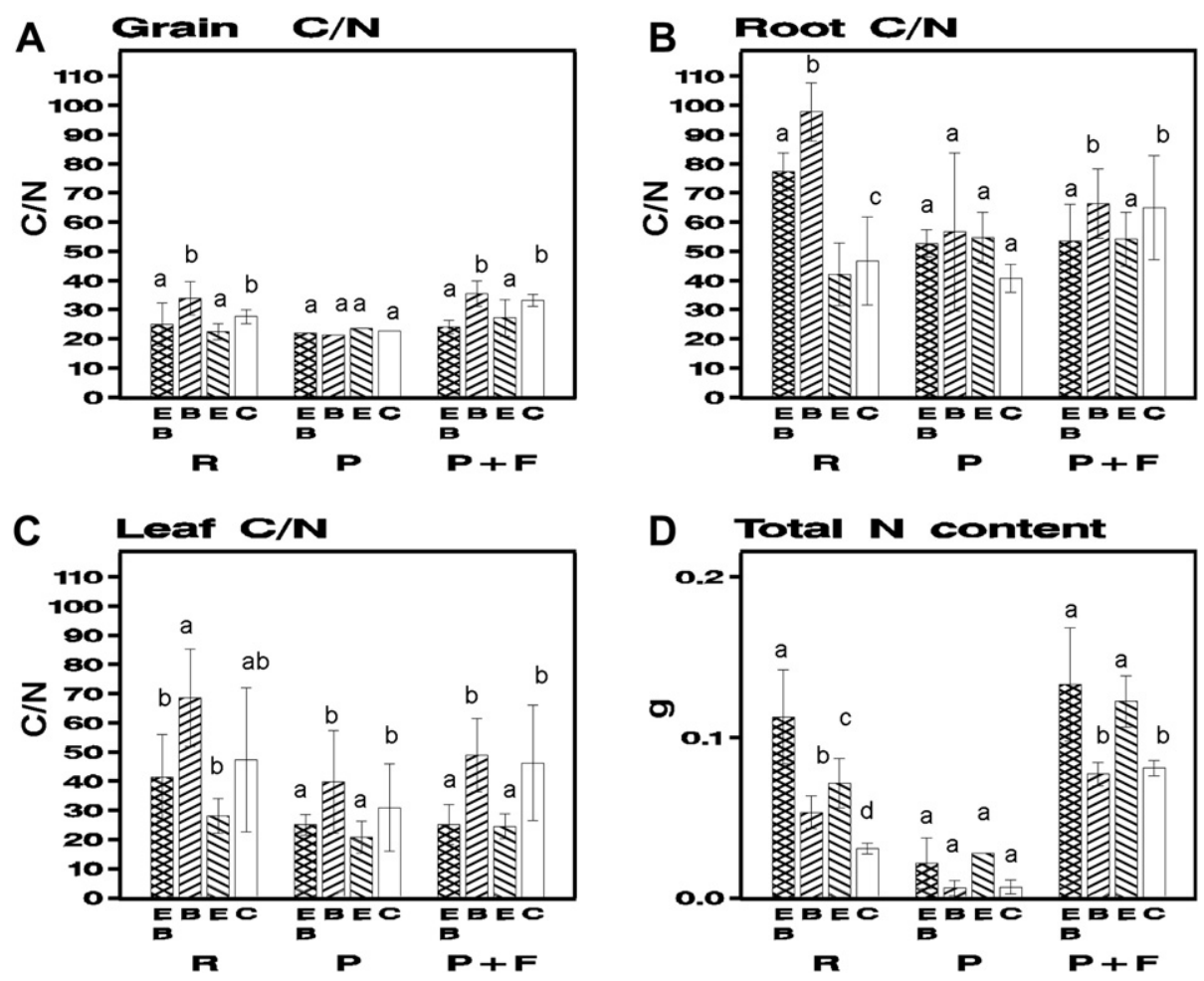

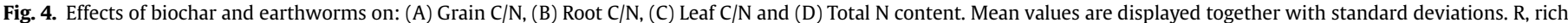

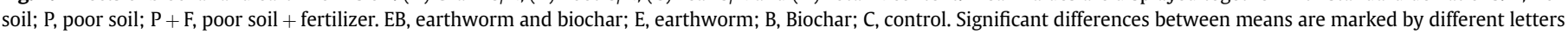
(least square means).

\subsection{Effects on roots}

Earthworms increased root biomass in the poor soil, as already reported in other earthworm experiments implemented in nutrient poor soils (Welke and Parkinson, 2003; Wurst et al., 2003). Three types of explanation can be proposed. They are respectively based on earthworm impact on minerlaization, the release of phytohormones, and soil porosity. Besides, more than one of these mechanisms could be involved. First, it is usually assumed that earthworms foster mineralization and thus the availability of mineral nutrient, as was found in our experiment. Plant would then increase their root biomass to take advantage of this increased resource availability (Wurst et al., 2004). It is more surprising that $P$. corethrurus also increased root biomass in the rich soil and in the fertilized poor soil. This could be due to the fact that earthworms increased the availability of mineral nitrogen in these two soil treatments, while the subsequent nutrient availability might not have reached the threshold above which root biomass no longer respond to nutrient availability. Alternatively this could be due to the fact that plant investment to their root system depends both on the global availability of mineral nutrients and on their local distribution in the soil (Ingestad and Agren, 1991; Bell and Sultan, 1999; Farrar et al., 2003). Here, fertilization globally increased nutrient availability but earthworm activities are likely to increase locally the availability of mineral nutrients, in their casts (Lavelle and Martin, 1992; Lavelle et al., 1999; Jimenez and Decaens, 2004; Mariani et al., 2007; Tapia-Coral et al., 2006). This could in turn stimulate locally the root production (Fitter, 1976; Wurst et al., 2003) which could increase the total root biomass in spite of the globally high nutrient availability. Second, earthworms are known to trigger the release of molecules recognized as phytohormones by plants (Muscolo et al., 1999). In particular, they have been shown to trigger the release of auxin-like molecules that increase root biomass (Pasqualeto Canellas et al., 2002). This could explain the maintenance of an increase in root biomass in the rich soil and with fertilization. Besides, it cannot be excluded that these two mechanisms are not also involved in the observed increase in root biomass in the presence of earthworms in the two unfertilized soil treatments. Third, another explanation is possible for the increase in root biomass whatever the soil treatment: earthworms are known to increase soil porosity through bioturbation and this could have allowed rice to grow more roots through the facilitation of root penetration in the soil.

Biochar is known to modify soil physicochemical parameters (Glaser et al., 2002; Lehmann et al., 2003a,b), which is likely to affect root biomass and architecture but has so far never been described. In all our soil treatments, and contrary to earthworms, biochar did not lead to an increase in root biomass. This could be due to the fact that biochar effect on the availability of mineral nitrogen is less clear than earthworm effect (no effect on ammonium in the rich soil, no effect on nitrate in the fertilization treatment). However, in the poor soil, earthworm and biochar effects on the availability of nitrate and ammonium are of the same magnitude $(+145 \%)$. Since, in this soil, earthworms but not biochar increased root biomass this suggests that nutrient availability is not the only mechanisms involved, as suggested above. Again, this suggests that either the release of phytohormones or an increase in soil porosity are involved in earthworm impact on root biomass.

The increase in the total root biomass in the presence of earhtworms, in the three soil treatments, manifested itself in the three variables measured to describe root architecture. Taken together, root biomass increased in all possible ways in presence of earthworms: total root length, mean root diameter and the number of root ramifications increased in presence of earthworms. Once again, biochar increased mineral nitrogen availability but did not lead to the same effect on roots as earthworms. As for the total root 
biomass, these results support the hypothesis that other factors than nutrient mineralization and availability are involved in earthworm effect on root system. This is also confirmed by the fact that (1) root ramification had the same general level in the three soil treatments, while nutrient availability clearly decreased from the fertilization treatment to the poor soil treatment treatment), (2) root ramification reacted to earthworms that led to smaller changes in mineral nitrogen availability.

In our study, earthworm and biochar effects on shoot/root ratio strongly varied with soil type: no effect in the poor soil, increase in the ratio with biochar in the rich soil, decrease in the ratio with earthworm in the fertilization treatment. These effects cannot be directly predicted from effects on the total root biomass: i.e. they result from the interaction between earthworm and biochar effects on the total biomass production and on resource allocation. Shoot/ root ratio is generaly though to be primarily determined by the availability of mineral nutrients (Wilson, 1988), which has been affected both by earthworms and biochar. However, the shoot/root pattern we observed is not well correlated with earthworm and biochar effects on mineral nitrogen availability. Taken together, these results on the shoot/root ratio and root system architecture suggest that biochar and earthworms have also directly modified resource allocation independently of their effect on mineralization and nutrient retention. This points again at earthworm effect on plant growth through the release of hormone-like molecules, which is known to influence the shoot/root ratio (Wilson, 1988; Atiyeh et al., 2002). Alternatively, earthworm effect on soil porosity might also have the same type of impact on the root system.

\subsection{Effects on grain production}

For all soil treatments, the total grain biomass and the grain number tended to exhibit the same tendency as the total biomass. However, neither earthworms nor biochar affected significantly the mean grain weight in the rich and poor soils. Besides, earthworms both decreased the mean grain weight and the total grain biomass in the fertilization treatment. This effect is not well correlated with the increase in nutrient availability in presence of earthworms. Indeed, earthworms increased the availability of nitrate (independently of biochar) and increased ammonium availability in the biochar treatment. This is again an effect of earthworms on resource allocation. It is correlated with earthworm positive effect on root biomass: in the fertilization treatment earthworms did no influence the total biomass, increased root biomass, and decreased the total grain biomass. It is not clear why rice should decrease its resource allocation to grain in the presence of earthworms in a fertilized soil, unless it is primarily an effect of an increase in the allocation to the root system.

\subsection{Effects on rice nitrogen content}

Earthworms tended to decrease the $\mathrm{C} / \mathrm{N}$ of all plant parts, even in the fertilization treatment, while biochar had small and less consistent effects on $\mathrm{C} / \mathrm{N}$. This effect parallels earthworm effect on mineral nitrogen availability: as usually acknowledged nutrient concentration in plants increase when nutrient availability increase (Lambers et al., 1988a; Ingestad and Agren, 1992). Such positive effect of earthworms on plant nutrient concentration have already been observed and attributed to their effect on mineralization (Brown et al., 2000; Araujo et al., 2004). It must however be marked that earthworm effect on leaf $\mathrm{C} / \mathrm{N}$ is not proportional to their effect on nutrient availability. For example, in the fertilization treatment, the $\mathrm{C} / \mathrm{N}$ decreased by $47 \%$ and mineral nitrogen availability increased by $12 \%$. Meanwhile, the decrease in the $\mathrm{C} / \mathrm{N}$ of grains and root was relatively much smaller (about 15\%). This suggests that rice resource allocation strategy interacts with earthworm effects: a large proportion of nitrogen made available by earthworms is allocated to leaves where it can enhance photosynthesis (Lambers et al., 1988b,c).

Both an increase in mineral nitrogen absorption (Lehmann et al., 2003a; Steiner et al., 2007, 2008) and a decrease in plant C/N have already been observed with the addition of biochar (Lehmann et al., 2003b). In our experiment, in the R soil, biochar decreased nitrogen concentration (increased the $\mathrm{C} / \mathrm{N}$ ) in rice, whereas biochar increased both ammonium and nitrate concentration in this soil. Again, effects of treatments on rice did not perfectly parallel their effect on mineral nitrogen availability and biochar and earthworm effects are different. In this case, an explanation could be that earthworms but not biochar increased root biomass in the rich soil, so that earthworms both directly increase nutrient availability and rice capacity to absorb nutrients. This emphasizes again the importance of earthworm effects on plant resource allocation. The decrease in rice $\mathrm{C} / \mathrm{N}$ in presence of biochar could be due to the fact that mineral nutrients maintained in the soil by biochar might not be perceived in the same way by plants as nutrients released by earthworms. For example, cations adsorbed on biochar might be poorly available to plants and thus could lead to an increase in root biomass (Lambers et al., 1988a; Wilson, 1988).

\subsection{Conclusion}

We found that earthworm and biochar effects highly depend on soil type and we found few evidences of positive interaction between earthworms and biochar. Hence, the combination of the two practices could be advised because they have positive additive effects but does not increase further crop production. Due to the fact that our experiment is a short-term microcosm experiment, it cannot however be excluded that earthworms and biochar could interact synergistically on the long term to increase the availability of mineral nutrients and crop production. Indeed, earthworms increase mineralization, and biochar is likely to increase nutrient retention, so that the two mechanisms could lead to the building up of a much larger nutrient stock (Barot et al., 2007; Boudsocq et al., 2009). It is possible that a part of the biochar effect in our experiment is due to such a mechanism triggered by the presence of earthworms in the field experiments from which we collected our soil.

The potential benefits of earthworms and biochar highly depend on soil type and on fertilization, which suggests that the use of biochar and earthworms should be more beneficial is some soil types than in other. It has already been recognized that earthworm effects depend on soil type (Brown et al., 2004a) and that the magnitude of earthworm effects does not necessarily decrease with soil fertility (Laossi et al., 2010). As far as we know, while biochar has been said to be beneficial in most tropical soils because they tend to be deprived of nutrients by an intense lixiviation (Lehmann et al., 2003c; Glaser and Woods, 2004; Asai et al., 2009), our experiment is the first one to attempt determining in which soil types biochar should be used. However, as for earthworms, it would be precocious, without further experiments, to predict which soil characteristics determine soil responsiveness to biochar in term of fertility and crop production. Indeed, in our experiment, the "poor" and "rich" soils differed by many other characteristics than their richness in mineral nutrients. To conclude on the interaction between biochar, earthworms and soil type, new experiments using soils with various textures, types of clay or content in organic matter are needed. Finally, the fact that both earthworms and biochar effects tended to disappear with mineral fertilization suggests that biochar and earthworms could be more beneficial 
instead of mineral fertilization than in combination with mineral fertilization. Other studies have suggested that biochar and mineral fertilization could increase fertility synergistically (Lehmann et al., 2003a; Steiner et al., 2007; Steiner et al., 2008). Our experiment does not support this view but this could again be due to the fact that it was not a long-term field experiment.

\section{Acknowledgments}

We are grateful to CIAT (TSBF CIAT Institute at Cali) for providing access to the field, logistics and laboratory facilities. We thank J. Major, D. Molina, Y. Ospina, M. Chatel, J. Cardoso, J. Polania, H. Mina, E. Melo, M. Recio, N. Asakawa, P. Hurtado, J. Ricaurte and A.De Paoli for help during the experiment. Plant biomass analyses were realised in the "Laboratoire des Moyens Analytiques of IRD" under the direction of Patricia Moulin. This study was supported by the ANR program "jeune chercheur 2005" through the SolEcoEvo project, (JC05_52230).

\section{References}

Amador, J.A., Görres, J., 2005. Role of the anecic earthworm Lumbricus terretris L. in the distribution of plant residue nitrogen in a corn (Zea mays)-soil system. Applied Soil Ecology 30, 203-214.

Araujo, Y., Luizão, F.J., Barros, E., 2004. Effect of earthworm addition on soil nitrogen availability, microbial biomass and litter decomposition in mesocosms. Biology and Fertility of Soils 39, 146-152.

Asai, H., Samson, B.K., Stephan, H.M., Songyikhangsuthor, K., Homma, K., Kiyono, Y., Inoue, Y., Shiraiwa, T., Horie, T., 2009. Biochar amendment techniques for upland rice production in Northern Laos 1 . Soil physical properties, leaf SPAD and grain yield. Field Crops Research 111, 81-84.

Atiyeh, R.M., Lee, S., Edwards, C.A., Arancon, N.Q., Metzger, J.D., 2002. The influence of humic acids derived from earthworm-processed organic wastes on plant growth. Bioresource Technology 84, 7-14.

Barot, S., Ugolini, A., Brikci, F.B., 2007. Nutrient cycling efficiency explains the longterm effect of ecosystem engineers on primary production. Functional Ecology 21, 1-10.

Bell, D.L., Sultan, S.E., 1999. Dynamic phenotypic plasticity for root growth in polygonum: a comparative study. American Journal of Botany 86, 807-819.

Bhattacharya, S.S., Chattopadhyay, G.N., 2004. Transformation of nitrogen during vermicomposting of fly ash. Waste Management \& Research 22, 488-491.

Blackwell, P., Riethmuller, G., Collins, M., 2009. Biochar application to soil. In: Lehmann, J., Joseph, S. (Eds.), Biochar for Environmental Management: Science and Technology. Earthscan, London, pp. 207-226.

Blouin, M., Barot, S., Lavelle, P., 2006. Earthworms (Millsonia anomala, Megascolecidae) do not increase rice growth through enhanced nitrogen mineralization. Soil Biology \& Biochemistry 38, 2063-2068.

Boudsocq, S., Lata, J.C., Mathieu, J., Abbadie, L., Barot, S., 2009. Modelling approach to analyse the effects of nitrification inhibition on primary production. Functional Ecology 23, 220-230.

Brown, G.G., Pashanasi, B., Villenave, C., Patrón, J.C., Senapati, B.K., Giri, S., Barois, I. Lavelle, P., Blanchart, E., Blakemore, R.J., Spain, A.V., Boyer, J., 1999. Effects of earthworms on plant production in the tropics. In: Lavelle, P., Brussaard, L., Hendrix, P. (Eds.), Earthworm Management in Tropical Agroecosytems. CABI Publishing, New York, pp. 87-137.

Brown, G.G., Barois, I., Lavelle, P., 2000. Regulation of soil organic matter dynamics and microbial activity in the drilosphere and the role of interactions with other edaphic functional domains. European Journal of Soil Biology 26, 177-198.

Brown, G.G., Edwards, C.A., Brussaard, L., 2004a. How earthworms effect plant growth: burrowing into the mechanisms. In: Edwards, C.A. (Ed.), Earthworm Ecology. CRC Press, Boca Raton, pp. 13-49.

Brown, G.G., Moreno, A.G., Barois, I., Fragoso, C., Rojas, P., Hernandez, B., Patron, J.C., 2004b. Soil macrofauna in SE Mexican pastures and the effect of conversion from native to introduced pastures. Agriculture Ecosystems \& Environment 103, 313-327.

Chaoui, H.I., Zibilske, L.M., Ohno, T., 2003. Effects of earthworm casts and compost on soil microbial activity and plant nutrient availability. Soil Biology and Biochemistry 35, 295-302.

Chatel, M., Ospina, Y., Rodriguez, F., Lozano, V., 2003. Mejoramiento convencional de arroz para ecosistemas de sabanas. Project IP-4. Improved Rice Germplasm for Latin America and the Caribbean. - CIAT (Centro Internacional de Agricultura Tropical), p. 23

DeLuca, T.H., MacKenzie, M.D., Gundale, M.J., Holben, W.E., 2006. Wildfire-produced charcoal directly influences nitrogen cycling in Ponderosa pine forests. Soil Science Society of America Journal 70, 448-453.

Domínguez, J., Bohlen, P.J., Parmelee, R.W., 2004. Earthworms increase nitrogen leaching to greater soil depths in row crop agroecosystems. Ecosystems 7, $672-685$.
Doube, B.M., Williams, P.M.L., Willmott, P.J., 1997. The influence of two species of earthworm (Aporrectodea trapezoides and Aporrectodea rosea) on the growth of wheat, barley and faba beans in three soil types in the greenhouse. Soil Biology \& Biochemistry 29, 503-509.

Farrar, J., Hawes, M., Jones, D., Lindon, S., 2003. How roots control the flux of carbon to the rhizosphere. Ecology 84, 827-837.

Fitter, A.H., 1976. Effects of nutrient supply and competition from other species on root-growth of Lolium-Perenne in soil. Plant and Soil 45, 177-189.

Gijsman, A.J., Oberson, A., Friesen, D.K., Sanz, J.I., Thomas, R.J., 1997. Nutrient cycling through microbial biomass under rice-pasture rotations replacing native savanna. Soil Biology \& Biochemistry 29, 1433-1441.

Glaser, B., Lehmann, J., Zech, W., 2002. Ameliorating physical and chemical properties of highly weathered soils in the tropics with charcoal - a review. Biology and Fertility of Soils 35, 219-230.

Glaser, B., Woods, W.I., 2004. Amazonian Dark Earths: Explorations in Space and Time. Springer, New York, 216 pp.

Glaser, B., 2007. Prehistorically modified soils of central Amazonia: a model for sustainable agriculture in the twenty-first century. Philosophical Transactions of the Royal Society B - Biological Sciences 362, 187-196.

Ingestad, T., Agren, G.I., 1991. The influence of plant nutrition on biomass allocation. Ecological Applications 1, 168-174.

Ingestad, T., Agren, G.I., 1992. Theories and methods on plant nutrition and growth Physiologia Plantarum 84, 177-184.

Jimenez, J.J., Decaens, T., 2004. The impact of soil organisms on soil functioning under neotropical pastures: a case study of a tropical anecic earthworm species. Agriculture Ecosystems \& Environment 103, 329-342.

Lambers, H., Stuart Chapin, F., Pons, T., 1988a. Mineral nutrition. In: Plant physiological ecology. Springer, New York, pp. 255-310.

Lambers, H., Stuart Chapin, F., Pons, T., 1988b. Photosynthesis, respiration, and long distance transport. In: Plant physiological ecology. Springer, New York, pp. 11-91.

Lambers, H., Stuart Chapin, F., Pons, T., 1988c. Growth and alocation. Springer, New York, pp. 321-67.

Laossi, K.R., Noguera, D.C., Bartolome-Lasa, A., Mathieu, J., Blouin, M., Barot, S., 2009 Effects of an endogeic and an anecic earthworm on the competition between four annual plants and their relative fecundity. Soil Biology \& Biochemistry 41 1668-1673.

Laossi, K.-L., Ginot, A., Noguera, D.C., Blouin, M., Barot, S., 2010. Earthworm effects on plant growth do not necessarily decrease with soil fertility. Plant Soils 328 109-118.

Lavelle, P., Martin, A., 1992. Small-scale and large-scale effects of endogeic earthworms on soil organic matter dynamics in soils of the humid tropics. Soil Biology \& Biochemistry 24, 1491-1498.

Lavelle, P., Brussaard, L., Hendrix, P., 1999. Earthworm Management in Tropical Agroecosystems. CABI, New York, 320 pp.

Lavelle, P., Barros, E., Blanchart, E., Brown, G., Desjardins, T., Mariani, L., Rossi, J.P., 2001. SOM management in the tropics: why feeding the soil macrofauna? Nutrient Cycling in Agroecosystems 61, 53-61.

Lavelle, P., Spain, A., 2001. Soil Ecology. Kluwer Academic Publishers, Dordrecht, 654 pp.

Lehmann, J., da Silva, J.P., Steiner, C., Nehls, T., Zech, W., Glaser, B., 2003a. Nutrient availability and leaching in an archaeological Anthrosol and a Ferralsol of the Central Amazon basin: fertilizer, manure and charcoal amendments. Plant and Soil 249, 343-357.

Lehmann, J., Kern, D.C., Glaser, B., Woods, W.I., 2003b. Amazonian Dark Earths. Origin, Properties, Management. Kluwer Academic Publishers, 505 pp.

Lehmann, J., Kern, D.C., German, L.A., McCann, J., Martins, G.C., Moreira, A., 2003c. Soil fertility and production potential. In: Amazonian Dark Earths: Origin, Properties, Management. KLUBER, pp. 105-124.

Lehmann, J., Rondon, M., 2006. Bio-char soil management on highly weathered soils in the humid tropics. In: Uphoff, N. (Ed.), Biological Approaches to Sustainable Soil Systems. CRC Press, Boca Raton FL, pp. 517-531.

Lehmann, J., Gaunt, J., Rondon, M., 2006. Bio-char sequestration in terrestrial ecosystems-a review. In: Mitigation and Adaptation Strategies for Global Change. Springer, pp. 403-427.

Major, J., 2009. Biochar Application to a Colombian Savanna Oxisol: Fate and Effect on Soil Fertility, Crop Production, Nutrient Leaching and Soil Hydrology. Faculty of the Graduate School of Cornell University, $152 \mathrm{pp}$.

Major, J., Lehmann, J., Rondon, M., Goodale, C., 2009. Fate of soil-applied black carbon: downward migration, leaching and soil respiration. Global Change Biology. doi:10.1111/j.1365-2486.2009.02044.x.

Mariani, L., Jimenez, J.J., Asakawa, N., Thomas, R.J., Decaens, T., 2007. What happens to earthworm casts in the soil? A field study of carbon and nitrogen dynamics in Neotropical savannahs. Soil Biology \& Biochemistry 39, 757-767.

Marris, E., 2006. Putting the carbon back: Black is the new green. Nature 442 , 624-626.

Muscolo, A., Bovalo, F., Gionfriddo, F., Nardi, S., 1999. Earthworm humic matter produces auxin-like effects on Daucus carota cell growth and nitrate metabolism. Soil Biology and Biochemistry 31, 1303-1311.

Pasqualeto Canellas, L., Olivares Lopes, F., Okorokova-Façanha, A.L., Rocha Façanha, A., 2002. Humic acids isolated from earthworm compost enhance root elongation, lateral root emergence, and plasma membrane $\mathrm{H}+$-ATPase activity in Maize roots. Plant Physiology 130, 1951-1957.

Pietikäinen, J., Fritze, H., 2000. Charcoal as a habitat for microbes and its effect on the microbial community of the underlying humus. Oikos 89, 231-242. 
Reynolds, H.L., Packer, A., Bever, J.D., Clay, K., 2003. Grassroot ecology: plantmicrobe-soil interactions as drivers of plant community strcuture and dynamics. Ecology 84, 2281-2291.

Rippstein, G., Amezquita, E., Escobar, G., Grollier, C., 2001. Condiciones naturales de la sabana. In: Agroecologia y Biodiversidad de las Sabanas en los Llanos Orientales de Colombia. Centro Internacional de Agricultura Tropical (CIAT), Cali, pp. $1-21$.

Rondon, M.A., Lehmann, J., Ramirez, J., Hurtado, M., 2007. Biological nitrogen fixation by common beans (Phaseolus vulgaris L.) increases with bio-char additions. Biology and Fertility of Soils 43, 699-708.

SAS, 1990. GLM procedure. In: SAS/GRAPH software, version 6, vol. 2. SAS Institute Inc., Cary, USA.

Scheu, S., 2003. Effects of earthworms on plant growth: patterns and perspectives. Pedobiologia 47, 846-856.

Sheehan, C., Kirwan, L., Connolly, J., Bolger, T., 2006. The effects of earthworm functional group diversity on nitrogen dynamics in soils. Soil Biology \& Biochemistry 38, 2629-2636.

Singh, B., Hatton, B., Singh, B., Cowie, A., Kathuria, A., 2010. Influence of biochars on nitrous oxide emission and nitrogen leaching from two contrasting soils. Journal of Environmental Quality 39, 1-12.

Steiner, C., Teixeira, W.G., Lehmann, J., Nehls, T., de Macedo, J.L.V., Blum, W.E.H. Zech, W., 2007. Long term effects of manure, charcoal and mineral fertilization on crop production and fertility on a highly weathered Central Amazonian upland soil. Plant and Soil 291, 275-290.

Steiner, C., Glaser, B., Teixeira, W.G., Lehmann, J., Blum, W.E.H., Zech, W., 2008 Nitrogen retention and plant uptake on a highly weathered central Amazonian Ferralsol amended with compost and charcoal. Zeitschrift Fur Pflanzenernahrung Und Bodenkunde. (Journal of Plant Nutrition and Soil Science) 171, 893-899.

Subler, S., Baranski, C.M., Edwards, C.A., 1997. Earthworm additions increased shortterm nitrogen availability and leaching in two grain-crop agroecosystems. Soil Biology \& Biochemistry 29, 413-421.

Tapia-Coral, S.C., Luizao, F.J., Barros, E., Pashanasi, B., Del Castillo, D., 2006. Effect of Pontoscolex corethrurus Muller, 1857 (Oligochaeta: Glossoscolecidae) inoculation on litter weight loss and soil nitrogen in mesocosms in the Peruvian Amazon. Caribbean Journal of Science 42, 410-418.

Tiessen, H., Cuevas, E., Chacon, P., 1994. The role of soil organic matter in sustaining soil fertility. Nature $371,783-785$

Topoliantz, S., Ponge, J.-F., 2003. Burrowing activities of the geophagous earthworm Pontoscolex corethrurus (Ologochaeta: Glossoscolecidae) in the presence of charcoal. Applied Soil Ecology 23, 267-271.

Topoliantz, S., Ponge, J.-F., Ballof, S., 2005. Manioc peel and charcoal: a potential organic amendment for sustainable soil fertility in the tropics. Biology and Fertility of Soils 41, 15-21.

Trujillo, W., Amezquita, E., Fisher, M.J., Lal, R., 1998. Soil organic carbon dynamics and land use in the Colombian savannas I. Aggregate size distribution. Soil Processes and the Carbon Cycle, 267-280.

Van Zwieten, L., Kimber, S., Morris, S., Chan, K.Y., Downie, A., Rust, J., Joseph, S., Cowie, A., 2009. Effects of biochar from slow pyrolysis of papermill waste on agronomic performance and soil fertility. Plant and Soil 327, 235-246.

Welke, S.E., Parkinson, D., 2003. Efefct pf Aporrectodea trapezoides activity on seedling growth oof Pseudotsuga menziesii, nutrient dynamics and microbial activity in different forest soils. Forest Ecology and Management 173 169-186.

Whalen, J.K., Parmelee, R.W., Subler, S., 2000. Quantification of nitrogen excretion rates for the three lumbricid earthworms using ${ }^{15} \mathrm{~N}$. Biology and Fertility of Soils 32, 347-352.

Wilson, J.B., 1988. A review of evidence on the control of shoot-root ratio, in relation to models. Annals of Botany 61, 433-449.

Wurst, S., Dugassa-Gobena, D., Scheu, S., 2004. Earthworms and litter distribution affect plant-defensive chemistry. Journal of Chemical Ecology 30, 691-701.

Wurst, S., Jones, T.H., 2003. Indirect effects of earthworms (Aporrectodea caliginosa) on an above-ground tritrophic interaction. Pedobiologia 47, 91-97.

Wurst, S., Langel, R., Reineking, A., Bonkowski, M., Scheu, S., 2003. Effects of earthworms and organic litter distribution on plant performance and aphid reproduction. Oecologia 137, 90-96. 